\title{
The Case of Nutcracker Phenomenon Associated With IgA Nephropathy
}

\author{
Danilo V. Medin ${ }^{1}$, Siniša O. Živković ${ }^{1}$, Dejan M. Ćelić ${ }^{1,2}$, \\ Sonja B. Golubovićn ${ }^{1,2}$, Bojana B. Ljubičić ${ }^{3}$, Sonja Lj. Šušnjević ${ }^{4}$, \\ Igor D. Mitić1,2
}

\author{
${ }^{1}$ Clinic of Nephrology and Clinical Immunology, Clinical Center of Vojvodina, Novi Sad, \\ Serbia \\ ${ }^{2}$ Faculty of Medicine, University of Novi Sad, Novi Sad, Serbia \\ ${ }^{3}$ Emergency Center, Clinical Center of Vojvodina, Novi Sad, Serbia \\ ${ }^{4}$ Institute of Public Health of Vojvodina, Faculty of Medicine, University of Novi Sad, Novi Sad, \\ Serbia
}

\section{SUMMARY}

Introduction: The nutcracker syndrome is a rare clinical entity caused by compression of the left renal vein by the superior mesenteric artery. Epidemiologically opposite, IgA nephropathy is the most common cause of idiopathic glomerulonephritis. A combination of the two diseases has previously been reported in a few cases.

Case Report: Herein we report a case of a 22-year-old male patient admitted because of macroscopic hematuria due to excessive oral anticoagulation. He had prior evidence of proteinuria, microhematuria, impaired kidney function, and enlarged left kidney. He presented with fatigue, abdominal pain, nausea, and several instances of vomiting after a meal. A diagnosis of left renal vein compression and IgA nephropathy was made based on clinical, laboratory, radiological findings and kidney biopsy. The vascular anomaly was treated conservatively, while steroids were given to treat glomerulonephritis. The result was complete regression of symptoms, normal laboratory findings, and a significant drop in proteinuria.

Conclusion: It is important to evaluate whether patients have nutcracker phenomenon before initiating treatment for IgA nephropathy and vice versa, as hematuria and proteinuria can be overlapping symptoms of both conditions. Renal biopsy should not be hesitated for differential diagnosis, and treatment should be highly individualized.

Keywords: IgA, Nephropathy, Nutcracker, Syndrome, Proteinuria, Hematuria

\section{INTRODUCTION}

The nutcracker syndrome is a rare clinical entity caused by compression of the left renal vein (LRV) by the superior mesenteric artery (SMA) as it passes between the SMA and the abdominal aorta $[1,2]$. The main symptoms are usually macro and microhematuria, and abdominal pain. Confirmation is done by ultrasonography, computed tomography, or magnetic resonance imaging (MRI). Treatment varies depending on patient characteristics and the severity of the symptoms. Open surgery is the first-line treatment, but some 
conservative treatment and endovascular surgery can also be employed [3]. It is important that diagnosis must be made after excluding other causes, because there are no accepted and clear clinical criteria.

IgA nephropathy is the most common cause of idiopathic glomerulonephritis. Although this disorder was initially thought to follow a benign course, it is now recognized that slow progression to end-stage renal disease occurs in up to $50 \%$ of affected patients [4]. The two major clinical presentations of IgA nephropathy are gross hematuria and persistent asymptomatic microscopic hematuria with or without mild to moderate proteinuria, which can also be seen in nutcracker syndrome caused by the nutcracker phenomenon.

\section{CASE REPORT}

A male patient, age 22, was admitted with macroscopic hematuria due to excessive oral anticoagulation. He was diagnosed with left brachial vein thrombosis four months earlier, which manifested as pain and swelling in the left shoulder, arm, and elbow, as well as swollen left axillary lymph nodes. He was treated with low molecular heparin, and switched to ongoing oral anticoagulation therapy with acenocoumarol. Further diagnostics revealed a mutation of the G1691A gene for coagulation factor $\mathrm{V}$. Laboratory tests incidentally also revealed proteinuria and microhematuria with elevated kidney function parameters, echo sonography showed an enlarged left kidney, with both kidneys hyperechogenic.

At present admission he also complained of fatigue, abdominal pain, nausea, and several instances of vomiting after a meal. Abdominal symptoms lasted for a few months, and at the same time he lost about 20 kilograms. At symptoms onset he recalls having red skin lesions around his ankles. He denied any hereditary disease in his family. He reported an allergy to paracetamol, was a non-smoker, denied alcohol or recreational drug use. Except of acenocoumarol and pantoprazole, he denied taking any medication daily. He denied any epidemiological risk factors and potential exposition to Coronavirus disease 2019 (COVID-19).

During initial admission the patient was awake and alert, vital signs showed normal body temperature $\left(36.7^{\circ} \mathrm{C}\right)$, sinus tachycardia of 120 beats per minute, blood pressure of
170/100 $\mathrm{mmHg}$, and a normal respiration rate. Heart and lung auscultation were unremarkable. The abdomen was moderately tender to palpation in the epigastrium and periumbilical region. There was no oedema of the limbs. No neurologic abnormalities were noted.

Initial laboratory analyses revealed the following: WBC $6.76 \times 10^{9} / \mathrm{l}$, RBC $3.29 \times$ $10^{12} / \mathrm{l}$, hemoglobin $95 \mathrm{~g} / \mathrm{l}$, HTC 0,3 , PLT 328 x $10^{9} / \mathrm{l}$, ESR $96 \mathrm{~mm} / \mathrm{h}$, urea $11.2 \mathrm{mmol} / \mathrm{l}$, creatinine $233 \mu \mathrm{mol} / \mathrm{l}$, CRP $169.5 \mathrm{mg} / \mathrm{l}$, uric acid $550 \mathrm{mmol} / \mathrm{l}$, pancreatic amylase $121 \mathrm{u} / \mathrm{l}$. His coagulation times were prolonged above the therapeutic threshold, with aPTT ratio of 3.87, and PT over 13.6. Lipid status was normal. The stool was positive for haemoglobin at one out of three samples, faecal calprotectin was $243.8 \mathrm{ug} / \mathrm{g}$. C3 and C4 levels were normal. Liver enzymes, bilirubin, and electrolytes were normal. The virus panel was unremarkable. Urine culture was negative. Urine was positive for proteins on semi-quantitative analysis $(++)$, and haemoglobin $(+++)$, there were 93 erythrocytes, and 10 leucocytes in $1 \mathrm{ml}$ of urine sediment. 24 hour proteinuria was 6105 $\mathrm{mg}$ per duiresis of $3000 \mathrm{ml}$. Serum protein electrophoresis was normal. The immunological panel revealed the following: Antinuclear antibodies (ANA) negative on primate liver cells, ANA weakly positive on Hep-2 cells with a homogenous pattern. Antibodies to double strained DNA (Anti DS DNA), ANA 8 panel, and antibodies to glomerular basement membrane were negative. PCR tests of nasopharyngeal and oropharyngeal swabs for severe acute respiratory syndrome coronavirus 2 (SARS$\mathrm{CoV}-2$ ) were negative.

Chest X-ray showed no pathological lesions. Ultrasonography of the abdomen showed enlarged left kidney $(14.5 \mathrm{~cm}$ longitudinally), poor corticomedullar distinction, no hydronephrosis. Both kidnyes were slightly hyperechogenic. The spleen seemed enlarged, over $13 \mathrm{~cm}$, homogenous structurally. Other organs were negative for apparent pathological lesions. Colonoscopy showed no pathological lesions.

MRI with angiography was performed (Picture 1), with following findings: left renal vein (arrow pointing on Picture 1) diameter was severely reduced at the origin of the superior mesenteric artery, no signs of thrombosis, differentially primary as part of a compressive „nutcracker” syndrome. Dynamic scintigraphy showed a slower radio- 


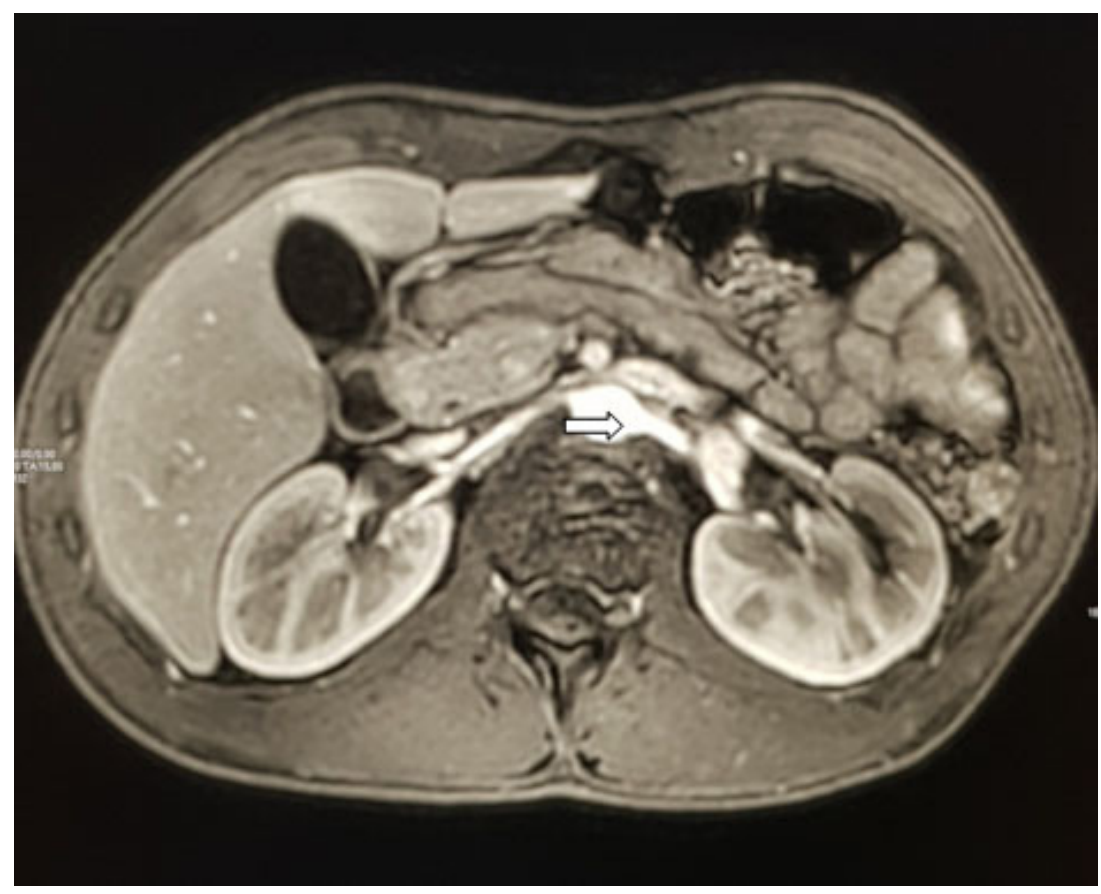

Picture 1. MRI angiography

pharmaceutical transit trough both kidney parenchymas, more marked on the right side. Global tubule function was reduced by $29 \%$, with relative functional kidney masses ratio 60\%:40\% left to right.

A right kidney biopsy was performed. Immunofluorescence microscopy showed 6 glomeruli with mesangial deposits and the following antiserums: $\mathrm{AGM}+/-, \operatorname{IgG}+, \operatorname{IgA}++$, IgM 0, C3 +/-, C4 0, F 0 (IgA pattern - Picture 2). Patohistological microscopy confirmed IF finding in the direction of mesangial proliferative glomerulonephritis. Mesangial proliferation, hypercellularity, focal fibrosis with rare lymphocytes was seen in the interstitium, neutrophil granulocytes were present in one tubule. Visible blood vessels were unremarkable. He was initially treated with broadspectrum antibiotics, intravenous saline solutions, low molecular weight heparin, and other prophylactic and symptomatic therapy. Control laboratory results showed a drop in acute phase reactants and blood urea and creatinine. Based on optical microscopy and immunofluorescence microscopy that was highly suspicious of IgA nephropathy, he was treated with oral corticosteroids, $60 \mathrm{mg}$ of prednisone with consecutive tapering.

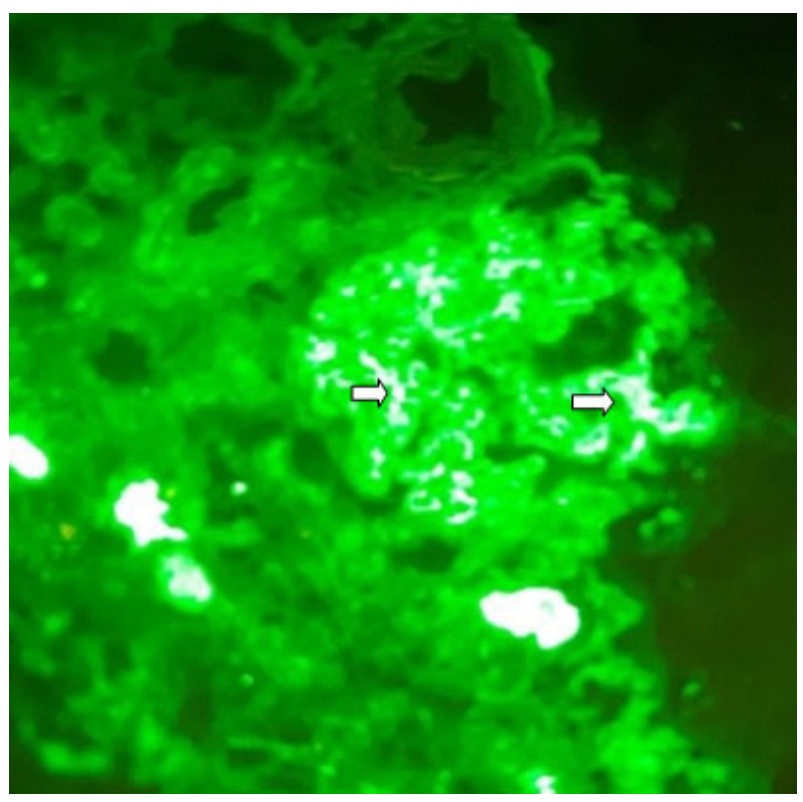

Picture 2. IgA pattern 
After discharge, he was presented to a vascular surgeon, who after careful examination of patient history and concomitant diseases, did not suggest any surgical or endovascular treatment, but conservative physical treatment to prevent superior mesenteric artery compression on the duodenum and left renal vein. On a first outpatient visit after initiation of corticosteroid treatment a month after, he was feeling well, complete blood count was normal, as well as urea, creatinine and electrolytes levels. CRP was $11.63 \mathrm{mg} / \mathrm{l}, 24$ hour proteinuria was $890 \mathrm{mg}$. IgA, IgG, IgM, kappa, lambda chains, serum proteins were normal. There were 15 to 20 erythrocytes in 1 $\mathrm{ml}$ of urine sediment. Prednisone was further tapered.

On the next control, the patient did not report any symptoms, he gained 14 kilograms since he was discharged from hospital. ANA was negative, with all other blood tests normal. 24 -hour proteinuria further dropped to $560 \mathrm{mg}$.

\section{DISCUSSION}

Left renal vein (LRV) entrapment is an anatomical condition characterized by extrinsic compression of the renal vein and consequently altered outflow in inferior vena cava (IVC), with demonstrable dilation of the hilar region and narrowing of the para-aortic region of the renal vein [5]. The term nutcracker phenomenon is used to refer to this specific anatomical condition when it is not associated with symptoms. Nutcracker syndrome, on the other hand, is the term used to define the LRV entrapment associated with a well-defined set of symptoms, and the severity of these clinical manifestations is related to the severity of anatomic and hemodynamic findings. The exact incidence of this anatomic variant is not defined, and it is considered underdiagnosed, as it is often paucisymptomatic or completely asymptomatic [5]. Hematuria is the most frequent sign. The pathogenetic mechanism proposed to explain hematuria is that increased venous pressure into the LRV and left gonadal vein can lead to rupture of the septa between the venules and the collecting system in the renal parenchyma. On the other hand, no specific glomerular damage is reported in the literature [6]. A contrast-enhanced computed tomography (CT) with both arterial and portal venous phase or magnetic resonance imaging
(MRI) using angiography sequences can be used to study the anatomy of the LRV and the relationships with the surrounding structures [7].

It is unclear whether the left renal vein entrapment in our patient should be called phenomenon or syndrome. While most of his symptoms could have been attributed to the renal vein compression, clinical and laboratory amelioration followed the treatment of the other concomitant disease with immunosuppressant medication. The anatomical condition was treated conservatively, a decision that proved sound in the patient followup. Conservative treatment is recommended for patients with discrete hematuria and mild symptoms [8]. Conservative treatment should be maintained for young patients, under the age of 18 years, as physical development, growth of connective and adipose tissue close to the origin of the SMA and between it and the LRV. Together with the formation of collateral veins, this may alleviate compression and venous hypertension, resulting in spontaneous remission of the condition.

Corticosteroids are the most studied immunosuppressant drugs used to treat IgA nephropathy. According to a large number of studies, treatment with steroids probably decreases end-stage kidney disease and annual GFR loss compared to no steroid regimen. Also, steroid treatment compared with no steroid treatment may increase complete remission [9]. The traditional paradigm is challenged by a recent study that found no significant improvement of outcome in patients with high-risk IgA nephropathy with the addition of immunosuppressive therapy. Also, during the 3-year study phase, more adverse effects were observed among the patients who received immunosuppressive therapy, with no change in the rate of decrease in the eGFR [10].

Cases of LRV entrapment combined with primary glomerular nephritis have been described, most of which were concurrent with IgA nephropathy and Henoch-Schoenlein syndrome [11]. In a Japanese study, the prevalence of LRV entrapment in IgA nephropathy was $6.8 \%$ [12]. Considering the relatively common combination of LRV entrapment and IgAN, a possible causal relationship between them has been found but not confirmed yet. 


\section{CONCLUSION}

It is important to evaluate whether the patients have the nutcracker phenomenon before initiating treatment for IgA nephropathy and vice versa, as hematuria and proteinuria can be the symptoms of both conditions. The combination may increase the complexity of the disease, and renal biopsy should not be hesitated with for differential diagnosis.

Treatment modalities should be highly individualized and optimized for every patient taking care of specific clinical aspects and implications, all of which are challenging for the physician.

Although the association between nutcracker phenomenon/syndrome and IgA nephropathy has not been established to this day, the high prevalence of left renal vein entrapment in IgA nephropathy requires further investigation by large studies.

\section{CONFLICT OF INTEREST}

All authors declare no conflict of interest.

\section{REFERENCES}

1. Daniels J, Griffiths M, Fisher E. Assessment and management of recurrent abdominal pain in the emergency department. Emerg Med J. 2020 Aug;37(8):515-521.

2. Zucker EJ, Ganguli S, Ghoshhajra BB, Gupta R, Prabhakar AM. Imaging of venous compression syndromes. Cardiovasc Diagn Ther. 2016;6(6):519-532.

3. de Macedo GL, Dos Santos MA, Sarris AB, Gomes RZ. Diagnosis and treatment of the Nutcracker syndrome: a review of the last 10 years. J Vasc Bras. 2018;17(3):220-228.

4. Imai N, Shirai S, Shibagaki Y, Kimura K. Nutcracker phenomenon in IgA nephropathy. Clin Kidney J. 2014;7(3):325-326

5. Ananthan K., Onida S., Davies A. Nutcracker Syndrome: An Update on Current Diagnostic Criteria and Management Guidelines. Eur. J. Vasc. Endovasc. Surg. 2017;53:886-894.

6. Ananthan K., Onida S., Davies A. Nutcracker Syndrome: An Update on Current Diagnostic Criteria and Management Guidelines. Eur. J. Vasc. Endovasc. Surg. 2017;53:886-894.

7. Lamba R., Tanner D., Sekhon S., McGahan J., Corwin M., Lall C. Multidetector CT of vascular compression syndromes in the abdomen and pelvis. Radiographics. 2014;34:93-115.

8. de Macedo GL, Dos Santos MA, Sarris AB, Gomes
RZ. Diagnosis and treatment of the Nutcracker syndrome: a review of the last 10 years. J Vasc Bras. 2018;17(3):220-228.

9. Kidney Disease: Improving Global Outcomes (KDIGO) Glomerular Diseases Work Group. KDIGO 2021 Clinical Practice Guideline for the Management of Glomerular Diseases. Kidney Int. 2021 Oct;100(4S):S1-S276.

10. Rauen T, Eitner F, Fitzner C, Sommerer C, Zeier $M$, Otte B et al. Intensive Supportive Care plus Immunosuppression in IgA Nephropathy. N Engl J Med 2015; 373:2225-223.

11. Wang C, Wang F, Zhao B, et al. Coexisting nutcracker phenomenon and superior mesenteric artery syndrome in a patient with IgA nephropathy: A case report. Medicine (Baltimore). 2021;100(28):e26611.

12. Imai N, Shirai S, Shibagaki $Y$, Kimura K. Nutcracker phenomenon in IgA nephropathy. Clin Kidney J 2014;7:325-6 


\title{
Slučaj „nutcracker” sindroma udruženog sa IgA nefropatijom
}

\author{
Danilo V. Medin ${ }^{1}$, Siniša O. Živković́ ${ }^{1}$, Dejan M. Ćelić ${ }^{1,2}$, Sonja B. Golubović, ${ }^{1,2}$, \\ Bojana B. Ljubičićc ${ }^{3}$ Sonja Lj. Šušnjević ${ }^{4}$, Igor D. Mitić1,2 \\ ${ }^{1}$ Klinika za nefrologiju i kliničku imunologiju, Klinički centar Vojvodine, Novi Sad, Srbija \\ ${ }^{2}$ Medicinski fakultet Novi Sad, Univerzitet u Novom Sadu, Novi Sad, Srbija \\ ${ }^{3}$ Urgentni centar, Klinički centar Vojvodine, Novi Sad, Srbija \\ ${ }^{4}$ Institut za javno zdravlje Vojvodine, Medicinski fakultet, Univerzitet u Novom Sadu, Novi Sad, Srbija
}

\section{KRATAK SADRŽAJ}

Uvod: „Nutcracker” sindrom predstavlja redak klinički entitet koji je uzrokovan kompresijom leve renalne vene od strane gornje mezenterične arterije. Suprotno ovom entitetu, IgA nefropatija predstavlja najčešći uzrok idiopatskog glomerulonefritisa. Kombinacija ove dve bolesti je do sada opisana u svega nekoliko slučajeva u svetu. Prikaz slučaja: Predstavljamo slučaj 22. godine starog pacijenta,muškog pola, koji je primljen na bolničko lečenje zbog makroskopske hematurije uzrokovane jatrogenom hipoprotrombinemijom. Pacijent od ranije ima identifikovanu proteinuriju, mikrohematuriju, poremećaj bubrežne funkcije i uvećanje levog bubrega. Klinički se prezentuje prisustvom slabosti, bolova u trbuhu, mučninom i u nekoliko navrata povraćanjem želudačnog sadržaja nakon uzetog obroka. Na bazi kliničkih, laboratorijskih i radioloških ispitivanja, kao i nalaza bioptata tkiva bubrega, postavljana je dijagnoza kompresije leve bubrežne vene i IgA nefropatije. Vaskularna anomalija je tretirana konzervativno, dok je glomerulonefritis lečen kortikosteroidnom terapijom. Rezulatat je bila kompletna regresija simptoma, laboratorijskih markera i značajan pad nivoa proteinurije.

Zaključak: Neopohodno je proceniti da li pacijent ima „nutcracker” sindrom pre započinjanja lečenja IgA nefropatije i obrnuto, jer hematurija i proteinurija mogu biti simptomi obe bolesti. Ne treba prezati od biopsije bubrega u cilju postavljanja definitivne dijagnoze, a terapija mora biti prilagođena svakom pacijentu ponaosob.

Ključne reči: IgA, nefropatija, nutcracker, biopsija, bubrega, proteinurija, hematurija 